\title{
FROM PROGRAMMING TO SYSTEM DESIGN
}

The First Twenty-five Years of Vocational Information

Technique Education in Finland

Lauri Fontell

ATK-instituutti, lauri.fontell@atk-instituutti.f

Abstract: The article outlines the evolution of vocational education from one-week programming courses to the two and a half year degree program. It focuses on how the contents of education have changed with the expansion of the use of information technique and with the development of computers. One of the more important questions addressed in this article is whether the employers in the field have considered the quantity and quality of instruction to be sufficient with respect to the demand of labor force in the country.

Key words: Vocational education, programming, system design.

\section{THE BEGINNING AND DEVELOPMENT OF TRAINING OF ADP PROFESSIONALS}

The training of ADP professionals in Finland began in the early 1960s when hardware importers started to organize basic courses in ADP and programming languages. In Finland, the most important companies involved in these activities were IBM and Suomen Kaapelitehdas, now known internationally as Nokia. The courses often consisted of only one week of instruction in the basics of ADP, followed by one week of instruction in programming languages. In government and business institutions that had to process large amounts of data, such as banks, insurance companies, and wholesale businesses, a need soon emerged for more extensive and longer instruction in ADP and in the designing of data systems for comprehensive processing of data. There was significant mobility in the labor force at the time, and thus these companies and public 
institutions continuously found themselves faced with a need to train new personnel.

To address this need for ADP instruction, they developed an information system design course. They offered the first course in November 1962 and it was four weeks long. A group of private individuals then founded a company called Tietojenkäsittelyneuvonta $O y$, 'ADP Consulting Ltd.', which took over the responsibility for these courses and began to develop their contents. People who in their work were involved in information systems design processes participated in these courses almost as a rule.

The first Finnish systems design model emerged from the course materials of the above mentioned courses and from the various research groups of an association called Tietokoneyhdistys - The Finnish Data Processing Association (FDPA). They used this model at many businesses and public institutions when they designed their systems; they also used it at different schools and at the universities in their instruction.

The need for professional training of programmers and ADP designers in the public sphere became ever more acute as the use of computers became more and more widespread. Various business corporations contacted the FDPA, asking it to lobby with the government in order that formal and government sponsored ADP instruction could begin in Finland. In 1967, the FDPA put together a committee, which would then elaborate and articulate suggestions on how they could do it.

The committee decided they would recommend the founding of a special vocational school that would give training in ADP skills. A new committee emerged with the task of developing this concept further. The new committee submitted its memorandum to the FDPA at the end of 1968. The FDPA then invited its member organizations to discuss the contents of this memorandum. The result of these discussions was that the founding of such an institution was necessary and thus another committee assembled to plan the execution of the decision to found such a school and to obtain any permission from the government that would be necessary for this purpose.

Some of the members of this third committee participated in a Scandinavian meeting in Bergen, Norway, in the spring of 1969 , and they also visited Sweden in order to acquaint themselves with the one year long training of programmers that was available in that country. Because of the work of this committee, the ATK-instituutti, 'The ADP Institute', was founded in Finland in February 1970 for the purpose of training programmers and ADP designers.

At first, the institute offered three-month courses, but as of the autumn of 1971, these courses became extended so that they lasted a complete year. The required basic education for these courses was a high school or vocational school diploma. From 1974 on, the institute also began to offer further training for those persons who already had acquired a basic education 
in the field. This further training was three semesters of instruction, which was not required to follow immediately one after the other. As of 1978, the basic course that the institute offered would last for $21 / 2$ years. Those who had completed this basic course received a datanome's diploma, the name for the degree borrowed from Denmark. From time to time, the faculty of the institute would compare the instruction it offered with the corresponding instruction given in Denmark. They did the comparison in conjunction with Allan Dresling's visits in Finland and later through the Finnish faculty's visits to Denmark.

Parallel to this line of instruction, the training offered by business colleges in ADP also became more extensive. In the autumn of 1969, the Riihimäki Business College started to offer a one-year course in ADP as supplementary education for business college graduates. This was the first course of its kind in Finland.

In their curricula, the ADP Institute and the business colleges in Finland focused on commercial and administrational ADP applications. These institutions did not address the training of maintenance personnel and programmers for technical tasks. At the end of 1970, the Ministry of Education formed a committee to investigate the need for instruction in this neglected area. The committee recommended that they establish a technical college. By chance, at the same time, some school facilities had become available in the town of Raahe in the Oulu Province. The committee found the premises in Raahe more than satisfactory, and thus they established a new technical college in Raahe in 1971. The graduates of the college would become ADP engineers and technicians. In the beginning, the college also offered half a year courses, and later one-year courses in programming.

In addition to these three institutions, three vocational education centers for adults began to offer instruction in the field, training programmers, computer operators, and keyboard operators. In addition, the Vocational School for the Visually Impaired, the present Arla Institute (Vocational Training and Development Center) in Espoo, near Helsinki, began to train visually handicapped persons as programmers.

Only around the mid-1980s was there a significant change in this situation. As the need for ADP professionals grew exponentially, the Ministry of Education had to appoint a committee to find a solution to the problem of how to address this need. The committee recommended that instruction in the field take place on a much wider scale than before. Fifteen business colleges and institutes now began to offer studies leading to the degree of datanome. Similar studies leading to the degree of computer engineers and technicians appeared in virtually all the forty schools of technical education in Finland.

The Ministry of Education initiated a public discussion on the possibilities of raising the quality of vocational education in the early $1990 \mathrm{~s}$, 
and this discussion lead to the plans to develop higher vocational schools into polytechnics. The scope of these plans included ADP instruction, too, with virtually all polytechnics having degree programs in ADP, beginning from 1992.

\section{THE VOLUME OF EDUCATION VS. THE NEED FOR EDUCATION}

\subsection{The number of computers in Finland}

In 1966, they estimated that there were approximately 5,000 ADP professionals in Finland. They also estimated that in the next few years, this number would grow by about 200 new professionals every year, because the number of computers was growing fast. By the time they established the first vocational school offering training in ADP 1970, the need for professionals in this field had become even more urgent, since no training in this field had existed in Finland between 1966 and 1970. The table below shows the trend of the number of computers.

\begin{tabular}{c|ccccccc}
\hline Year & 1958 & 1961 & 1964 & 1967 & 1970 & 1973 & 1976 \\
\hline $\begin{array}{c}\text { The number of } \\
\text { computers }\end{array}$ & 1 & 12 & 65 & 155 & 206 & 317 & 5500 \\
\hline
\end{tabular}

\subsection{ADP Professionals in Finland}

In 1977, the Finnish National Data Delegation and the FDPA published a study on the need for ADP professionals and the educational programs that could produce such professionals. In 1974, 167-trained programmers graduated from vocational schools, and three years later, the number had increased to 235, while there were also 58 persons who completed the advanced training course. This means that not until 1977 was the Finnish educational system able to reach the level that had been considered necessary a decade earlier. Now there were $86 \mathrm{ADP}$ engineers and technicians graduating from the Raahe Technical School every year. In the 1977 study, it showed the need that the educational system should be able to produce 318 graduates from the vocational schools each year. However, towards the end of the 1970 s, the economic recession caused a decrease in the investments in the business sector of the country, and thus the demand for ADP professionals did not grow as had been expected. 
As microcomputers became more common in the early 1980's, the demand for ADP professionals increased dramatically. As the length of the basic program that the ADP Institute had offered had extended, the institute had reduced the number of new students it had accepted. Now however, they decided to increase the number of new students to the level originally planned, that is, to 120 students per year.

In the spring of 1984, the Ministry of Education appointed a committee to survey the situation. The committee recommended that the number of new students to be admitted to the program for the datanome degree be increased from the then current 120 to 350 new students, and that 700 new students be admitted to the basic program for ADP technicians. The training of ADP technicians had already spread from Raahe to several other technical schools. The Ministry of Education immediately granted permission to accept 426 new students for the datanome programs in various business schools everywhere in the country. Thus, the ministry's actions clearly exceeded the recommendations of the committee, and this was actually more adequate as far as the needs in the labor market were concerned, since it turned out that the number of people working in the field grew by $20 \%$ every year around that time. However, this increasing trend slowed down for a few years when a severe economic recession hit Finland in the early 1990s, its effects being here much worse than elsewhere in the world.

The committee had also recommended that basic training be available to graduates of business and technical schools. The committee estimated that it would be necessary to admit 600 to 700 students per year to this supplementary training program, but in 1985 , only 110 students attended to it, which meant that proposal of the committee did not become reality as the number of new students did not really increase. This led to a situation in which non-ADP professionals persons who had to make use of ADP in their work did not have a chance to acquire the necessary knowledge on ADP that would have enabled them, for example, to discuss their problems and needs with the ADP professionals. The following table shows the growth of the number of the ADP professionals.

\begin{tabular}{c|ccccc}
\hline Year & 1963 & 1965 & 1971 & 1974 & 1976 \\
\hline Total & 1950 & 3050 & 7109 & 8581 & 9926 \\
Designers & 150 & 370 & 1006 & 1768 & 2178 \\
Programmers & 200 & 340 & 928 & 1095 & 1138 \\
\hline
\end{tabular}




\section{FROM PROGRAMMING TO SYSTEMS DESIGN}

As mentioned earlier, the hardware importers were giving training to ADP professionals in the first phase. The main emphasis was on the basics of ADP and on programming languages. The programming courses arranged by the importers focused mainly on teaching the programming language used by the hardware that the importers had in their stock. The courses were one week long, that is, they consisted of about 30 to 36 hours of instruction. The designer course in 1962 was four weeks long, consisting of 140 hours of instruction. Out of this, $7 \%$ were devoted to basics, $9 \%$ to programming, $32 \%$ to systems design, and $37 \%$ to descriptions of implemented systems.

When the degree programs began, the amount of time used for instruction had increased manifold. At the same time, there was also a change in the required basic education for these programs. In the early days, many of those coming to this field had a university level degree or a diploma from a college level institution. Now the majority of those studying in these programs were high school graduates. The one-year courses focused mainly on programming and tasks related to programming. The total amount of instruction offered was 1,200 hours. Out of this, programming took 40$45 \%$, while information systems design received only $10 \%$ of the instruction hours. In addition to this, instruction was offered in the basics of ADP, business management, English, verbal and written communication skills and mathematics.

Judging from the results of a questionnaire directed at employers and at those graduates who had worked in the field for at least two years, the instruction offered at this point met its objectives to the following degree: The employers gave a rating of 3.3 and the graduates a rating of 3.8 - the maximum rating would have been 5 . To the question of whether the offered subjects were relevant to the skilled needed in work situations, the rating given by both groups was 4.1. The employers voiced an opinion according to which more emphasis should take place to the methods and tools of information systems design.

As I mentioned above, systems design played only a minor role in the training of programmers. The reason for this was the fact that they considered systems design was something for which there were two important preconditions to satisfy if one were to pursue it successfully: a university degree and a good knowledge of the field for which one would be designing the systems. In spite of this general prejudice in the field, the ADP Institute began to offer an advanced degree program for programmers containing $53 \%$ of systems design, $7 \%$ of programming and general information on the field, and $9 \%$ of communication and language studies. 
The aim of the degree program was to produce technical ADP designers, not designers who would work on entire information systems.

Towards the late 1970s, everyone in the ADP field realized that the era of pigeonholes was over. Teams were designing ADP systems and the members of the teams participated both in planning and in implementation. It was now necessary to widen the scope of the instruction. The answer to this challenge was the program for the degree of datanome.

The amount of instruction offered in this program was 3,100 hours, out of which work practice as an intern took $22 \%$. In the early stages of this program, the systems design was given $14 \%$ of the instruction hours and programming was allotted $24 \%$. As the program evolved, the allotted amount of instruction changed so that systems design increased its share to $16 \%$ and the share of programming decreased to $20 \%$. A final project became part of the program and they estimated that it accounted for $7 \%$ of the work needed for the degree. As the time needed to complete the program increased, the number of instruction hours allotted to both programming and systems design increased significantly. The following table shows this progress.

\begin{tabular}{|c|c|c|c|c|c|}
\hline Education & $\begin{array}{l}2 \text { week } \\
\text { course }\end{array}$ & $\begin{array}{l}\text { Design } \\
\text { Course }\end{array}$ & $\begin{array}{c}\text { Programmer } \\
1 \text { year }\end{array}$ & $\begin{array}{c}\text { Adp-designer } \\
1,5 \text { years }\end{array}$ & $\begin{array}{l}\text { Datanome } \\
2,5 \text { years }\end{array}$ \\
\hline Year & $1960 \mathrm{~s}$ & 1962 & $1970 \mathrm{~s}$ & $1974-$ & $1978-$ \\
\hline Duration, hours & 80 & 140 & 1210 & 1330 & 3135 \\
\hline \multicolumn{6}{|l|}{ Content* } \\
\hline Basics & 50 & 7 & 10 & 4 & 7 \\
\hline Programming & 50 & 9 & 41 & 3 & 20 \\
\hline System design & & 32 & 5 & 23 & 15 \\
\hline Business & & 37 & 8 & & 10 \\
\hline Language & & & 8 & 9 & 10 \\
\hline Mathematics & & 8 & 5 & 4 & 4 \\
\hline Practice & & & 17 & 53 & 22 \\
\hline Final Project & & & & & 7 \\
\hline Others & & 7 & 6 & 4 & 5 \\
\hline & 100 & 100 & 100 & 100 & 100 \\
\hline
\end{tabular}

* The content of education in percent 


\section{THE DEVELOPMENT OF THE CONTENTS OF INSTRUCTION}

On the basic level, programming techniques were dependent on the available hardware and the programming language it used. It was already in the 1960 s when they discovered the problems relating to the management of programs. They realized that the program they used had a logical organization and they could divide its functions into modules. The various businesses involved developed program libraries, into which they collected the modules that they needed in more than one system. There was a development toward universally applicable modules using parameters. An upper limit to the size of a module could be given as a maximum number of commands allowed. The intention behind this was to make the programs more transparent and to increase the potential to test them.

As the ADP Institute began its operation in the early 1970s, it was necessary to offer a new subject that would be partly independent of whatever programming language the students were studying. This new subject was called programming techniques. The idea was to investigate the implemented data systems and look for functions that most systems utilize. Standard program algorithms began part of these functions. Among these functions were, for example, punch card input, reporting, processing of tables, processing of sequential files, and verification of the social security number. The basic functions of the modules were performed by the most important sentences of the programming language being used. These functions were data input, data writing, data transfer, comparison of data, and arithmetic functions. The programs were documented either with flowcharts or by semi-programming. There were also attempts to teach decision table technique, but this did not gain much ground. Methods for designing programs began to appear around the world in the 1970s and among these methods, JSP gradually became the most important one. This mode of thinking, developed by Jackson, was widely adopted in the $1980 \mathrm{~s}$.

To reduce the amount of time needed for programming, there were efforts in various parts of the world to develop computer-aided software engineering (CASE tools). This meant, among other things, that computer systems should be able to produce programming code based on the documentation of the system analyst. Thus, the focus in ADP training was shifting towards analyzing and designing systems.

The preconditions for the evolution of the systems development training were the creation of suitable teaching materials and the description of well functioning implemented systems. The first systems design course, held in 1962 , had in fact consisted of the sharing of personal experiences that people involved in the field had accumulated. This was the basis of the 
development of system design methods in Finland and the sphere of the FDPA largely carried out this development work.

The starting point for this work was a book by Eero Kostamo called Atksysteemien suunnittelun perusteista, 'On the Foundations of Information Systems Design', published 1965. This book begins from the general systems theory and covers the entire systems design field, ending with software engineering phasing. Indeed, from this book on, phasing became the dominant mode of approach in the field in Finland.

It became important to be able to work methodically. Miikka Jahnukainen collected into his book Atk-systeemien dokumentointi ja standardointi, 'The Documentation and Standardization of ADP Systems', published 1966, the procedures and rules of documentation used by business enterprises and government institutions in Finland.

A working group appointed by the FDPA produced in 1968 a book describing the model of systems design adopted in Finland in more detail than Mr. Kostamo had done in his book. This book was called ATKsysteemityön rakenne ja sisältö, 'The structure and contents of ADP systems design', and the model it described came to be called the hålkaka or hålbröd model, if one were to use its Swedish name, from the traditional Finnish kind of rye bread that is round in its shape and has a hole in the middle. This name for the model reflected the recurring cycles one would go through, as the system would evolve.

In this model, the main phases of systems design were research, designing, implementation, and maintenance. The model emphasized the fact that this kind of work consisted essentially of tasks that were iterative in their nature. During the life span of an ADP system, these phases would repeat as the applications become more and more expanded and the methods of data processing evolve further and further. The main phases divided into subphases, and these they described by spelling out the aims, contents, and tasks of the systems and the results they expected to produce. This publication would then be useful for years and years by the students of the field.

The next textbook that shaped the evolution of systems design appeared in 1974. The ADP Institute had appointed a working group in which people from the business and government spheres participated. The basis for the work of this working group came mostly from Sweden, from the publications on the theoretical framework for systems design and the methods that had been developed in this area in that country.

The working group produced a booklet called Tietosysteemin rakentaminen, 'Constructing ADP Systems', 1974, and the booklet was nicknamed "hammer and nail", the expression having been derived from its cover illustration. The booklet presented a basic vocabulary that the working group had adopted, beginning from the functions and management 
of institutions or businesses all the way to the operation of ADP systems. They placed more emphasis than before on the importance of ADP systems when they were integrated into the basic functions of the institutions or businesses.

The structure of an ADP system appeared into four areas; that is, (1) its functions, (2) data, (3) design of manual tasks, and (4) computerized tasks. A total of 38 different system design tasks were identified, and depending on their nature, these were assigned to one of the four areas mentioned above. They found that designing an ADP system is always a project, and that is why they gave the planning and the management of the designing process special emphasis. In the guiding the process of system design, phasing was used as a guiding principle. In the process, those of the 38 tasks that they found to be necessary in the designing of a particular system were divided into different phases. The idea was that in the designing work it would be possible to make use of the various phasing models found in the literature.

All the way until the early 1980s, the instruction in the ADP field in Finland centered on the designing and maintenance of centralized data systems. As microcomputers became more common and they evolved into more and more intelligent data terminals, the ways of constructing data systems began to change. This development also made it possible to experiment with prototyping with the microcomputers. In addition, the maintenance and updating of old ADP systems became important aspects of developing ADP systems. Using these needs as its starting point, the working group strove to improve the model for systems design. The product of this work was a book called Tietojenkäsittelyn kehittämismalli, 'The developing model of data processing', published in 1987. It was nicknamed "The Windmill", as it had on its cover a picture of a windmill with six vanes and an axle, illustrating the seven different vantage points used in the book. These were: (1) the development of the functional unit in question as a whole, (2) the development of the functions in the target area, (3) improving the human input in the unit, (4) the development of data banks, (5) the development of data communication channels, (6) the development of the contents of computerized tasks, and (7) the development of ADP solutions.

In addition to the model itself, the methods of design also developed. It was common to use conceptual analysis, that is the "entity-relation" method, and as well as the normalizing in the development of data banks. The wall posting technique, or the SSA Structured Systems Analysis, or YSM Yourdon Structured Method or the Finnish TISMA methods also guided the process of system design and its documentation. Either these methods came from the literature or they were the results of internal planning and management practices of various institutions or businesses. 


\section{SUMMARY}

Vocational training in the ADP field in Finland evolved in close cooperation with institutions and businesses that were using ADP. Thus, a person trained in ADP skills always had the preparation for the tasks that would await him or her in the future job. However, there was always a shortage of skilled workers in this field. The output of the educational system never met the demand for work force that the employers in the field had. Nevertheless, it has been true that the quality of ADP in Finland in the spheres of commerce, administration, and technology has always ranked among the best in the world. 